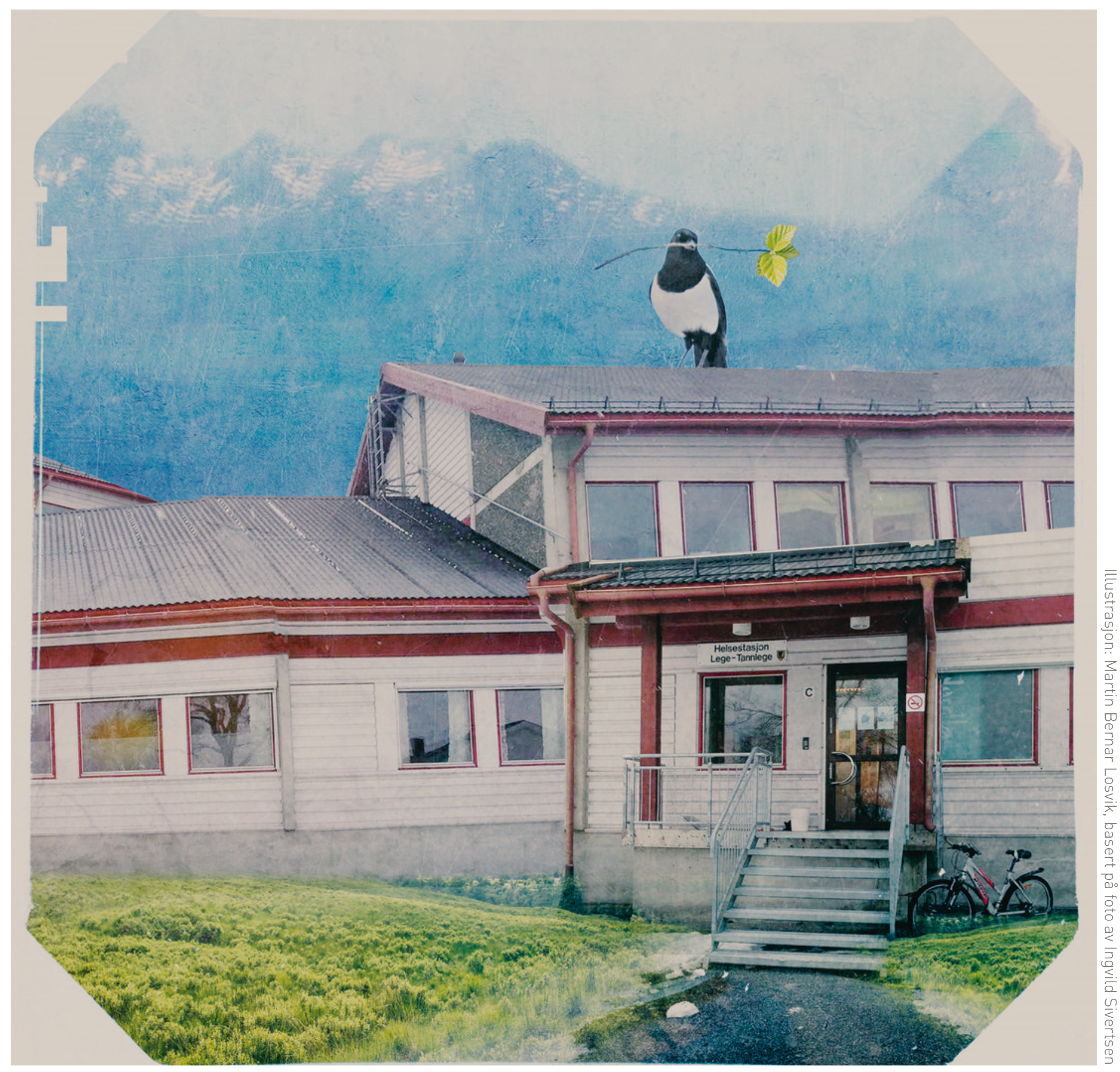

\title{
Nesna legekontor
}

(i)

Dersom du kjører Fylkesvei 17 på Helgelandskysten i Nordland, kalt Kystriksveien - en av verdens vakreste reiseruter - passerer du gjennom Nesna. Kommunen består av tettstedet Nesna samt øyene Hugla, Handnesøya og Tomma. Legekontoret finner du i kommunesentrumet Nesna, der det også er butikker og andre servicetilbud og Nord-Norges nest eldste institusjon for høyere utdanning, den tidligere lærerhøyskolen, nå en del av Nord universitet. 